\section{THREE YEARS OF MY LIFE UNDER THE SOUTHERN CROSS.}

By Thomas Lowe Laxton, L.R.C.P. Edin., M.R.C.S. Eng., SURGEON TRANSVAAL STATK ARTILLERY.

Leaving the River Thames by steamer on Nov. 9th, 1892, I arrived at Durban on Dec. 6th, and after spending a few weeks in that beautiful town I obtained the post of resident surgeon to Grey's Hospital, Pietermaritzburg, also in the colony of Natal. My patients here were of every race, nationality, and colour. The Kaffirs display marvellous recuperative powers after even the most severe injuries, especially of the head, their skulls being remarkably thick and dense; but when they are attacked by disease of an acute type their power of resistance compares most unfavourably with that of the whites. I was particularly struck with the frightful ravages that syphilis has made and is making amongst the natives, expecially among the Zulus in Natal since the death of.Cetewayo, uncler whose government the punishment for contracting syphilis was death either by impalement on a stake or burial alive. Pregnancy occurring in an unmarried female was also under the same regime punished with death. I noticed also that syphilis was virulent amongst the natives when it had been contracted from a white person and also among the white men infected by native women. Among the children of the natives scabies when neglected produces very severe effects, such as large suppurating sores, ulcerations of the skin, and general emaciation. After leaving Pietermaritzburg I spent six months at Barberton, where malarial fever is common, although neither so prevalent nor so severe in type as formerly. I then, in company with some friends, set out by waggon for Buluwayo in Matabeleland, which was then very little developed, but on arriving in the middle of June, 1894, at Pietersburg, a town in the north of the Transvaal and on the main road between Pretoria and Buluwayo, I found that military operations against the Kaffir chief Malaboch were in progress and that medical assistance was needed. I therefore volunteered my services, being anxious to see the Boers on the war-path, and to gain an insight into commando life and Kaffir warfare generally. The commandant general, P. J. Joubert, of Majuba and Langs Nek fame in the English war, received me most courteously and I immediately went to the front. The enemy's position was on the top of a high mountain called Blaauwberg, and it took us four hours' hard climbing to reach it, but the labour was well repaid by the beauty and grandeur of the scenery. The campaign had been conducted with only partial success owing to the physical difficulties of the situation and to the unwillingness of the commandantgeneral to risk the lives of his men in attempts to rush the positions occupied by the rebels, but want of food and water compelled them to surrender during the last days of July. and early in August the camp was broken up and we returned to Pietersburg. Between thirty and forty were killed on the side of the Boers in this small campaign, besides several of the native allies.

[Operations were almost immediately resumed against a number of petty chieftains, including Modjaji (the celebrated "She" of Rider Haggard) and Magoeba. The latter held out the longest, but was killed about the middle of June, 1895.]

The natives are marvellously resourceful in their treatment of fractures, applying numerous small sticks closely woven together by string or stout grass and binding them firmly round the limbs after the fructured ends have been placed in apposition. Immediately after the termination of the campaign against Magoeba I was sent by the Transvaal Government as medical officer to the famous warm baths at Waterberg, some eighty miles north of Pretoria. 'This water has a very high reputation amongst the Boers, and I must admit, both from my own experience and that of others, that its medicinal properties are of no common order. I have seen marvellous effects produced by it in cases of gout, rheumatism, lithiasis, intractable neuralgias and neuroses, callous ulcers, wounds of long standing, and various forms of bone and joint disease, especially of a scrofulous origin. I have not been able to obtain an analysis of the water, but I am given to understand that it contains an unusually large proportion of lithia salts. The water rises abundantly and with great force and is nearly at the boiling point.

In the beginning of October of last year $I$ was appointed surgeon to the State Artillery with the rank of captain, and for my services to the Government was made a full burgher of the Transvaal. Since then I have witnessed the defeat and capture of Dr. Jameson and his troopers at Doornkop, near Krugersdorp, particulars of which are so recent that I need not enter into details beyond stating that I was the Government medical officer placed in charge of the officers and men while prisoners in this country, and that all the wounded when sufficiently recovered were handed over to my care for transference to the Imperial authorities at the Natal border. Most, if not absolutely all, of Jameson's wounded were struck by Martini-Henry bullets, while the few burghers that were either killed or wounded-nine in allwere struck by Lee-Metford ammunition (Maxim gun or rifle). The majority of Jameson's men were wounded in the extremities. Fifteen received bullets in the right side of their bodies-namely, one in the jaw, two in the upper ex. tremities, and twelve in the lower extremities. Eight were wounded in the left side, three in the upper extremities, and five in the lower. Three men were also wounded in the back and one through the bladder and intestines; of the remainder solne were suffering from fractures, dysentery, abscesses, \&c. and injuries not due to bullets. Three of the troopers underwent amputation-one above and two below the knee. 0 the wounded burghers who were brought into hospital one had his brain traversed by a bullet, but nevertheless survived for te $n$ days, one was wounded through the abdomen, one through the right lung, and one through both hand and lung: there were also five suffering from illness and injuries not caused by bullets. Considering the amount of ammunition expended by Jameson's column it is marvellous how few casualties occurred among the Bosrs-a result which was not due to bad shooting, but to the careful manner in which the burghers seek and obtain cover. Several of Jameson's troopers told me that the mag*azinfs of their rifles were practically useless, for the least portion of rust, dirt, or grit renders the mechanism unworkable; the rifles also became so hot that they could not be grasped with the hand, and some of the older men said tbat they longed for the Martini-Henry rifle which they had previously used.

IMIIUNISATION AGAINST SERPENTS VENOM AND THE TREATMENT OF SNAKE-BITE WITH ANTIVENENE.

BY T. R. FrASER, M.D., F.R.C.P.EDIN., LL.D.ABERD., F.R.S., PROFESSOR OF MATERIA MEDICA AND CLINICAI MEDICINE AT THE UNIVERSITY OF EDINBURGH.

Professor Fraser delivered an interesting address before the Royal Institution of Great Britain on March 20th. His subject was Immunisation against Serpents' Venom and the Treatment of Snake-bite with Antivenene, and the following is an abstract of bis remarks :-

Traditions originating at a remote period and statements contained in the narratives of travellers-several of which were quoted-strongly suggest that human beings may acquire a power successfully to resist the toxic effects of serpents' venom. There is evidence, further, that venomous serpents are themselves protected to a considerable degree against their own venom and that of other serpents. These statements suggested to the lecturer the importance of experimentally investigating the subject, for if they were proved to be correct results would be obtained likely to be of value in the treatment of snake-bite in man. Some twenty years ago the sollecting of venom was begun for this purpose, and soon facts were obtained which showed that by the administration of a succession of minute doses of venom animals became able to resist a lethal dose without any distinct injury. The first supplies of venom failed at this point and the investigation was not resumed until several years afterwards. In the meantime, the results of experiments on the toxines of disease had suggested to others that serpents' venom might, like those toxines, be able to produce protection in animals. Starting with Sewall's experiments of 1886, an account was given of the work of other investigators, until those of Phisalix and Bertrand, made in 1893, and of Calmette, made in 1894, were described. The lecturer chiefly used tho 
wenom of the cobra of India in his experiments, but the leading experimental results obtained with it were reproduced with the venoms of several serpents of Australia, Africa, and America. The minimum lethal dose for a number of animals was first defined, and the protection was produced by a series of gradually increasing doses, until rabbits were able to receive, without injury, fifty times the minimum lethal dose, and in the course of five or six months a total quantity sufficient to kill 370 animals of the same species and weight. The blood-serum of these animals, called by the lecturer "antivenene," was next tested as an antidote, and having been found to be efficacious the limits of its antidotal power were defined in several series of experiments. The results appeared to justify the opinion that the antidotal action is a chemical and not a physiological one. The question-bearing also upon the antitoxins of disease- of the origin of this antidotal substance was discussed. In connexion with it the lecturer stated that he had found that by the stomach administration of antivenene, and more remarkably of cobra venom itself, an antivenomous substance could be introduced into the blood in a quantity sufficient to prevent death after the subcutaneous injection of more than the lethal dose of venom. Experiments were described in which from 500 to 1000 times the subcutaneous lethal dose of venom were introduced into the stomach of animals, and although no definite toxic symptoms were produced by these enormous quantities still the animals had become so far protected that within a few hours afterwards they were able to receive with almost no injury a dose of venom injected under the skin one-half larger than that which was able to produce death. These facts suggest that the antivenene is actually a normal constituent of the venom itself, and that the venom while in the stomach had been subjected to a process of analysis, whereby the poisonous constituents had failed to be absorbed into the body or had been destroyed, while the constituent or constituents which are antidotal had passed into the body in sufficient quantity to protect the animals against otherwise lethal administrations of venom. The measures to be employed in the treatment of snake-bite, including the administration of antivenene, were finally explained, and it was concluded that by its use human life could be saved in a considerable if not in a large proportion of cases that would otherwise terminate in death.

\section{THE HISTORY, METHODS, HINDRANCES, EXPENDTTURE, AND POLICY OF THE CIVIL RIGHTS DEFENCE COMMITTEE.} (Continued from page 1090.)

EARLY in 1894, on the initiation of the West Indian Alliance, the Civil Rights Defence Committee was formed. On March 5th a deputation of members and friends of the Alliance and of gentlemen not connected with the Alliance but who were interested in the successful vindication by Mr. Anderson of his own rights and in the establishment of the principles and rights of general and public interest to be upheld by Mr. Anderson in his appeals to the Judicial Committee of the Privy Council was organised to enlist the coopperation of the London and Counties Medical Protection Society in supporting Mr. Anderson and enabling him to prosecute the appeals to the Privy Council to obtain a reversal of the decisions in the cases of Marshall and Wife, Frank and Taylor. In reply to the deputation the London and Counties Medical Protection Society adopted resolutions that the decisions in the suit of Marshall and Wife $v$. Anderson are such as to seriously and unjustly affect the freedom of action of medical men in the practice of their profession and are matters of concern to all medical men, that it concerns the honour as well as interests of the profession to support the appeal of $\mathrm{Mr}$. Anderson to the Privy Council, and that the proceedings in Trinidad were opposed to the absolutely assured rights of British subjects, and advised the nomination of a committee to issue an appeal to the medical profession. This led to the formation of a joint committee composed of members nominated respectively by the London and Counties Medical Protection Society and the West Indian Alliance, which issued invitations to public bodies to send representatives to the Committee, and in response to these invitations the British Medical Association, the
West London divisions of the London and Counties Medical Protection Society and the Incorporated Medical Practitioners' Association, the West Indian Union, and the Trinidad and Dominica branches of the Union nominated representatives to the Committee. Shortly afterwards the Council of the Royal College of Surgeons of England also sent two representatives. The first appeal was issued by the Committee to about 1500 of the leading men in the profession, the amount of individual subscriptions being limited to 1 guinea. Subscriptions to the amount of $£ 120$ came in, and many strong expressions of opinion that the wrongs done vitally affected the honour and interests of the medical profession. After this, as further subscriptions came in slowly, Mr. Anderson, with the full approval of the Committee, appealed personally in Augus' and September, 1894, to every Fellow of the Collegeabout 1100 in number on the Register-bringing in about 35 guineas at a cost of $£ 15$ to $£ 18$. Some votes were passed by branches of the British Medical Association, and some subscriptions raised amongst members of branches. In April, 1894, Mr. Anderson gained the verdict of a Middlesex special jury for $£ 500$, Lord Coleridge entering judgment for the defendant on the ground that the action did not lie against a judge, and this judgment was confirmed in August by the Master of the Rolls, Lord Esher, and the Court of Appeal. When this judgment in Anderson $v$. Gorrie was pronounced by the Appeal Court, the Committee took this serious violation of Mr. Anderson's rights into consideration, and came to the conclusion that the best way of dealing with it would be by forming a new and powerful committee. The next important measure was the preparation of a formal report, under the title of an interim report, giving the investigations of the Committee and its conclusions with much of the evidence on which they were based together with the very strong opinions of the medical papers, professional public bodies, and professional men-an extraordinary weight of authority and opinion. The report was issued under the date Dec. 4th, 1894, but not struck off till later.

On Dec. 18th a printed letter from Lord Stamford giving a précis of the case and strongly appealing to the public for support was sent to two hundred and fifty leading newspapers in London and the provinces, but excepting a brief abstract in the Times and short notices in a few other papers it did not receive insertion or comment. Finding that the subject of judicial immunity was little understood or appreciated Mr. Anderson prepared with the approval of the Committee a short review of the subject with authorities, and it was published by the committee under the title of "The Doctrine of Judicial Immunity." Shortly afterwards "An Appeal to Public Men and Public Bodies" was prepared and published. Copies of the "Interim Report" "The Doctrine of Judicial Immunity," and "The Appeal to Public Men and Public Bodies," with a covering letter from Lord Stamford multiplied in the office, were sent to all the corporations and all the guilds, about eighty in number of the City of London, to every member of the House of Lords and House of Commons and to about 400 leading barristers, with apparently very little result either in moral support or funds. Just before the issue of the interim report THE LANCET had inserted a most earnest appeal for help in the work of the Committee and had opened a fund, heading it with a subscription of 10 guineas, but only one subscription of 5 guineas followed.

Efforts were next made to enlist the interest of some of the leading London papers. The St. James's Gazette, Pall Mall Gazette, and City Press consented to receive deputations headed by Lord Stamford. Upon this the $s t$. James's Gazette and Pall Mall Gazette inserted an appeal from the Committee signed by Lord Stamford and many members, accompanied by a strong paragraph in support of the appeal. This resulted in a subscription of 10 guineas from a member of the jury who tried Mr. Anderson's action and a few other subscriptions also continued to flow in. As soon as Mr. Anderson became aware that when Lord Esher had adjudicated in his appeal Mr. Yeatman's action against Lord Esher was in progress he took legal opinion and was advised that the proper course was to move the Court to set aside the decision as voidable and to re-enter the appeal for hearing. Accoradingly, at the end of July and beginning of August, 1895, he gave notice of his motions (1) to set aside as voidable the judgment of the Court of Appeal, and (2) on that motion being struck out of a motion to reinstate it in 